\title{
PENGEMBANGAN USAHA SAYURAN DAUN SINGKONG UNTUK PEMENUHAN KEBUTUHAN DAPUR UNIDA DAN RUMAH MAKAN PADANG BAGI UPT AGROTEKNOLOGI
}

\author{
Umi Isnatin ${ }^{1}$, Use Etica ${ }^{2}$ \\ ${ }^{1,2}$ Program Studi Agroteknologi, Fakultas Sains dan Teknologi \\ Universitas Darussalam Gontor \\ Email: umiisnatin@unida.gontor.ac.id ${ }^{1)}$
}

\begin{abstract}
The Technical Implementation Unit of agrotechnology as an entrepreneurial development for the student of agrotechnology at the University of Darussalam Gontor has a problem at the managerial level. The management indicator referred to is cultivation management, finance, and marketing. Therefore, this research emphasizes the program on improving students' managerial abilities for 4 months. The purpose of this study is as a means of learning for students in cultivating cassava plants for entrepreneurship. One thing that must be improved is the cultivation of cassava leaves and how to market them. Furthermore, the availability of cassava leaves (Manihot utilisima) refers to the production of cassava plants, and up until this point, there is no special cultivation for cassava leaves. The method used in this research is the practice of cultivating cassava and holding training in making Bhokasi and POC fertilizers, training in making vegetable pesticides, training for post-harvest and product packaging. This service activity will help to succeed in improving student skills as well as practicing cassava cultivation and building marketing networks in the UNIDA Gontor's business units and Padang restaurant as one of the restaurants that use cassava leaves the most.
\end{abstract}

Keywords: Cassava cultivation, cassava leaf business opportunities, Padang restaurant.

\begin{abstract}
Abstrak. UPT Agroteknologi sebagai lokasi pengembangan kewirausahaan mahasiswa prodi Agroteknologi Universitas Darussalam Gontor masih belum maksimal dalam pengelolaan. Indikator pengelolaan yang dimaksud adalah pengelolaan managemen budidaya, keuangan dan pemasaran. Pengabdian kami fokuskan pada program peningkatan kemampuan mahasiwa selama 4 bulan. Tujuan dari kegiatan ini sebagai sarana belajar mahasiswa dalam budidaya tanaman singkong yang akan diambil daunnya dan wirausaha. Salah satu yang akan kita tingkatkan adalah budidaya daun singkong dan cara pemasarannya. Daun singkong (Manihot utilisima), selama ini ketersediaannya mengacu kepada produksi tanaman singkong, dan belum ada budidaya khusus untuk sayur daun singkong. Adapun metode kegiatan yang kami lakukan adalah praktek budidaya tanaman singkong dan mengadakan pelatihan pembuatan pupuk Bhokasi dan POC, pelatihan pembuatan pestisida nabati, pelatihan pasca panen dan pengemasan produk. Kegiatan pengabdian ini berhasil peningkatkan kemampuan mahasiswa sekaligus praktek budidaya tanaman singkong dan membangun jaringan pemasaran di dapur UNIDA Gontor dan Rumah Makan Padang. .
\end{abstract}

Kata kunci: Budidaya tanaman singkong, Peluang bisnis daun singkong, rumah makan padang.

\section{PENDAHULUAN}

Mitra dalam usulan PPUPIK (Program Pengembangan Unit Produk Intelektual Kampus) pada hibah internal ini adalah UPT (Unit Pelaksana Teknis) Agroteknologi. Unit Pelaksana Teknis (UPT) Agroteknologi merupakan salah satu unit usaha dibidang pertanian yang ada di Universitas Darussalam Gontor. Kegiatan yang dilakukan di UPT diantaranya budidaya pertanian; perikanan dan perternakan. UPT Agroteknologi mulai berdiri pada bulan Oktober 2019 dengan luas lahan kelola 1,1 Ha. Terdiri atas lahan budidaya sayuran $0,5 \mathrm{Ha}$, lahan perikanan dan peternakan $0,5 \mathrm{Ha}$ dan sisanya belum dikelola. Adapun permasalahan yang dihadapi mitra (UPT Agroteknologi) adalah pengeloaan manajemen, kepengurusan yang sering ganti personil, teknik budidaya tanaman singkong yang diambil sayur.

UPT Agroteknologi dipilih sebagai lokasi pengabdian dengan pertimbangan dapat dikembangkan sebagai sarana belajar mahasiswa untuk berwirausaha dan inkubator bisnis yang menjanjikan. Mitra pengabdian skema PPUPIK mempunyai peran menyediakan lokasi dan peserta pelatihan.

Fasilitas dan pendanaan UPT

Agroteknologi diberikan oleh Yayasan Pondok Darussalam Gontor dan tambahan swadaya dari Prodi Agrotenologi. UPT Agroteknologi sebagai 
sarana praktek langsung para mahasiswa dalam budidaya tanaman, perikanan, peternakan dan meningkatkan kemampuan managemen. Juga sebagai sarana bagi Dosen untuk mengaplikasikan Tri Dharma Perguruan Tinggi di bidang Pengabdian.

Berdasarkan analisa usaha, budidaya tanaman sayuran daun singkong mempunyai prospek yang baik, sehingga pengembangan usaha sayuran daun singkong untuk pemenuhan kebutuhan dapur Unida Gontor dan rumah makan Padang bagi UPT Agroteknologi perlu ditingkatkan penangannya. Manffat lain dari daun singkong adalah sebagai pakan alternatif ternak (Askar, 2006). Akan tetapi sampai saat ini produksi sayuran daun singkong atau produk yang lain belum bisa maksimal. Permasalahan lain yang tidak kalah penting adalah managemen pemasaran yang belum terbentuk dengan baik, pengelolaan pumbukuan keuangan (akuntabilitas) masih kurang.

Singkong atau ubi kayu (Manihot esculenta Cranz atau Manihot utilissima Pohl) termasuk dalam famili Euphorbiaceae, mempunyai daun berbentuk tangan, batang beruas-ruas dan bercabang, tumbuh tegak, serta ketinggiannya dapat mencapai tiga meter.

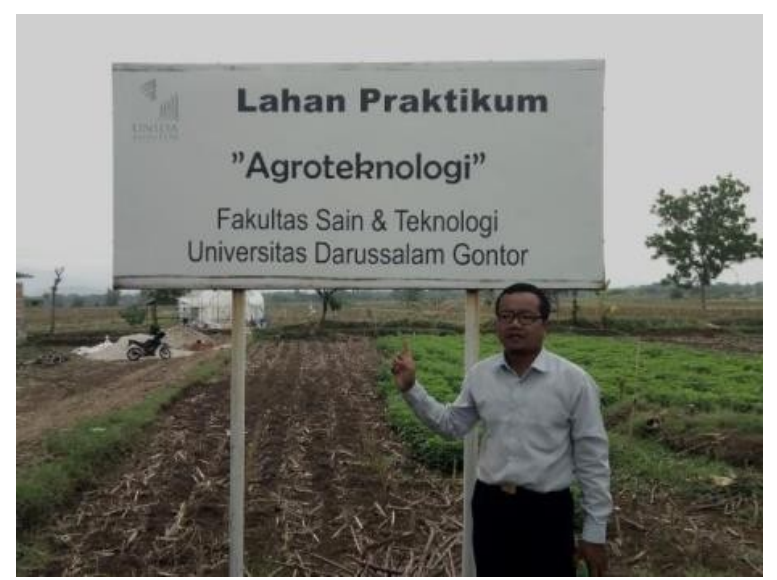

Gambar 1. Lokasi mitra di UPT
Daunnya menjari dengan variasi panjang, elip dan melebar, dengan warna hijau kuning dan hijau ungu serta warna tangkai hijau, merah, kuning atau kombinasi dari ketiga warna tersebut (Mahmud et all, 1990).

Daun dari beberapa jenis tanaman mengandung protein tinggi, salah satu diantaranya adalah daun singkong (Manihot utilisima). Ketersediaan daun singkong mengacu kepada produksi tanaman singkong. Daun singkong merupakan salah satu sayuran hijau yang digunakan sebagai sumber zat besi. Zat besi yang terkandung dalam $100 \mathrm{~g}$ daun singkong yaitu sebesar

2,0 g. Daun singkong dapat dijadikan sebagai salah satu sayuran yang baik dikonsumsi, mudah didapat dan mudah diolah. Keseimbangan besi dalam tubuh harus dipertahankan agar tubuh tidak mengalami anemia. Daun singkong (Manihot utilisima) merupakan sayuran hijau yang dapat digunakan sebagai sumber zat besi untuk hemoglobin darah. Namun demikian, proses pengolahan daun singkong masih terbatas (lakitan, 1995).

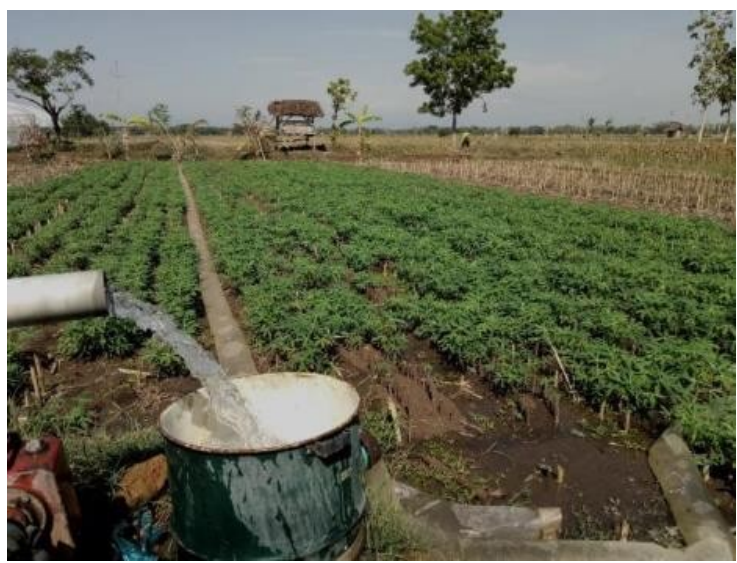

Agroteknologi Unida Gontor. 
Tabel 1. Solusi permasalahan dan dan luaran yang ditargetkan

\begin{tabular}{|c|c|c|c|c|}
\hline No & $\begin{array}{l}\text { Deskripsi } \\
\text { Permasalahan }\end{array}$ & Solt & Yang Ditawarkan & Luaran \\
\hline \multicolumn{5}{|c|}{ A. Produksi Sayuran Daun Singkong } \\
\hline \multirow[t]{2}{*}{1.} & $\begin{array}{l}\text { Pengendalian Hama } \\
\text { penyakit tanaman }\end{array}$ & 1.1 & $\begin{array}{lllr}\text { Memilih } & \text { tanaman } & \text { yang tahan } \\
\text { terhadap } & \text { serangan } & \text { hama dan } \\
\text { penyakit } & & & \end{array}$ & $\begin{array}{l}\text { Mitra (UPT Agro) } \\
\text { memproduksi tanaman yg } \\
\text { tahan terhadap hama da } \\
\text { penyakit }\end{array}$ \\
\hline & & 1.1 & $\begin{array}{l}\text { Pemasangan pembatas lahan } \\
\text { dengan jaring/paranet }\end{array}$ & $\begin{array}{l}\text { Serangan hama dan } \\
\text { penyakit berkurang }\end{array}$ \\
\hline 2. & $\begin{array}{l}\text { Peningkatan kemampuan } \\
\text { teknis tentang pertanian } \\
\text { organik khususnya sayur } \\
\text { daun singkong }\end{array}$ & 2.1. & $\begin{array}{l}\text { Adanya sekolah lapangan/ pelatihan } \\
\text { teknis tentang pupuk organik, } \\
\text { pestisida organik dan pengendalian } \\
\text { HPT. }\end{array}$ & $\begin{array}{l}\text { Mitra (UPT Agro) } \\
\text { mendapatkan peningkatan } \\
\text { pemahaman teknis pertanian } \\
\text { organik. }\end{array}$ \\
\hline 3. & $\begin{array}{l}\text { Proses produksi } \\
\text { pertanian organik } \\
\text { daun singkong, } \\
\text { belum memiliki } \\
\text { standarisasi. }\end{array}$ & 3.1 . & $\begin{array}{l}\text { Standarisasi produk pertanian } \\
\text { organik daun singkong }\end{array}$ & $\begin{array}{l}\text { Mitra UPT Agro mendapatkan } \\
\text { produk pertanian organik } \\
\text { sesuai dengan standar yang } \\
\text { telah ditentukan. }\end{array}$ \\
\hline
\end{tabular}

\begin{tabular}{llll}
\hline 4. & Produksi dan & Menjembatan & \multicolumn{2}{c}{ kerjasama antara Mitra UPT Agro mendapat } \\
persedian produk & mitra dengan petani & tambahan pasokan produk \\
pertanian tidak & lain / program lain, seperti & pertanian yg sehat dan baik \\
mencukupi & program kawasan rumah & (halal 7 toyib) \\
permintaan & pangan lestari &
\end{tabular}

\begin{tabular}{lll} 
4.2. & $\begin{array}{l}\text { Meningkatkan keterampilan } \\
\text { pengembangan kerjasama mitra } \\
\text { pemasok produk pertanian. }\end{array}$ & $\begin{array}{l}\text { Mitra UPT Agro mendapat } \\
\text { tambahan anggota } \\
\text { pemasok/petani }\end{array}$ \\
\hline
\end{tabular}

\begin{tabular}{|c|c|c|c|c|}
\hline \multicolumn{5}{|c|}{ B. Pemasaran } \\
\hline \multirow[t]{2}{*}{1.} & $\begin{array}{l}\text { Peningkatan } \\
\text { manajemen usaha } \\
\text { (pemasaran) }\end{array}$ & 1.1. & $\begin{array}{l}\text { Sharing tentang manajemen } \\
\text { pemasaran, manajemn pasok dan } \\
\text { pembukuan keuangan. }\end{array}$ & $\begin{array}{l}\text { Mitra UPT Agro mempunyai } \\
\text { pembukuan yang rapi lengkap } \\
\text { sesuai dengan kaedah } \\
\text { pembukuan. }\end{array}$ \\
\hline & & 1.2 . & $\begin{array}{l}\text { Membangun jaringan pemasaran } \\
\text { tingkat daerah (sekabupaten } \\
\text { Ponorogo) dan dapur Unida Gontor } \\
\text { yang saling menguntungkan sesuai } \\
\text { syariat islam. }\end{array}$ & $\begin{array}{l}\text { Mitra UPT Agro mempunyai } \\
\text { jaringan pemasaran tingkat } \\
\text { daerah dan dapur-dapur } \\
\text { Unida } \\
\text { Gontor }\end{array}$ \\
\hline 2. & $\begin{array}{l}\text { Produk halal dan } \\
\text { toyib }\end{array}$ & 2.1. & $\begin{array}{l}\text { Filosofi pengembangan } \\
\text { pertanian organik } \\
\text { sesuai syariat islam }\end{array}$ & $\begin{array}{l}\text { Mitra UPT Agro dan } \\
\text { anggota petani/komunitas } \\
\text { mempunyai landasan } \\
\text { yang kuat dan islami } \\
\text { dalam melaksanakan } \\
\text { budidaya pertanian } \\
\text { Organik. }\end{array}$ \\
\hline
\end{tabular}




\section{METODE PELAKSANAAN}

Metode yang digunakan dalam Pengembangan Usaha Sayuran Daun Singkong Untuk Pemenuhan Kebutuhan Dapur Unida dan Rumah Makan Padang Bagi UPT Agroteknologi adalah :

1. Praktek budidaya tanaman singkong yang diambil daunnya, mulai dari pemilihan bibit, persiapan bibit, pengolahan tanah, penanaman, dan pemeliharan.

2. Panen dan pasca panen.

3. Pemasaran. Ditambah dengan berbagai pelatihan untuk meningkatkan managemen UPT dan strategi pemasaran.

Program Pengembangan Unit Produk Intelektual Kampus (PPUPIK) yang berorientasi pada usaha produksi sayuran bidang pertanian organik di UPT Agroteknologi dengan urutan metode

:menerapkan keterpaduan atau sinergisme antara kegiatan produksi di lapangan, pembangunan ekonomi dan pembanguanan sosial (empowermwnt) dengan peningkatan Capacity building dan Technical Building. Berikut tahapan metode pelaksanaan PPUPIK:

a. Bahan Baku

Bahan baku yang tersedia adalah lahan budidaya pertanian dengan luas 1,1 $\mathrm{Ha}$, Bibit tanaman sayuran yang sebagian sudah ditanam, berbagai alsintan ( hand traktor, mesin diesel),cangkul,sabit, knapsak sprayer,alat perangkap hama. Panen dapat dilakukan secara berkala mulai dari umur 2-3 bulan, Alternatif bila produksi belum dapat memenuhi adalah dengan ekstensifikasi /perluasan lahan dan intensifikasi /kegiatan yang meningkatkan produksi, peningkatan teknologi pertanian. Pasar hasil panen daun singkong adalah dapur UNIDA Gontor dan masakan Padang di sekitar kota Ponorogo.

b. Proses Produksi

Proses produksi yang sudah berjalan di UPT Agroteknologi adalah mulai dari pengolahan lahan, persiapan bibit, penanaman, pemeliharaan, pengelolaan panen dan pasca panen.Peralatan yang dimiliki alsintan dan paket teknologi pertanian. Penjaminan mutu dari hasil panen sayuran UPT (terutama daun singkong) adalah dengan menjaga kualitas daun singkong dan kotinuitas panen secara berkala.

c. Managemen

Managemen yang dikelola mulai dari menyiapkan jadwal kegiatan (persiapan lahan, persiapan bibit, penanaman, pemeliharaan ,panen, pemasaran. Rencana produksi mulai 23 bulan tanam dengan pemenuhan kebutuhan dapur UNIDA Gontor dan Depot masakan Padang di sekitar Ponorogo. Pembenahan pengelolan pembukuan keuangan (akuntasi). Pelatihan managemen .Dengan begitu UPT akan dapat mengetahui berapa persedian barang yang dimiliki dari pasar yang harus dipenuhi.

\section{d. Pemasaran}

Dengan Skema PPUPIK berharap potensi pasar semakin luas karena produksi juga semakin meningkat. Bintoro dan Harris, (2006) menyatakan bahwa perluasan jaringan pemasaran dapat menjadi potensi pangsa pasar baru. Penambahan luas lahan dan teknologi pertanian akan meningkatkan produk dan kontinuitas panen. Teknik pemasaran dengan membangun jaringan pemasaran mulai dari mengenalkan produk ke dapur- dapur UNIDA Gontor , menjalin kerjasama dengan berbagai depot masakan Padang, atau mulai menawarkan lewat online dengan kemasan yang lebih menarik atau mulai ada wacana untuk membuat kemasan daun singkong dalam bentuk kering.

e. Pelatihan

Berbagai pelatihan juga diberikan pada para mahasiswa yang melaksanakan kewirausahaan di UPT, diantaranya pelatihan pembuatan pupuk Bhokasi dan POC (Pupuk Organik Cair), pelatihan pembuatan pestisida nabati, pelatihan panen dan pasca panen.

\section{HASIL DAN PEMBAHASAN}

Hasil pengabdian skema PPUPIK di UPT Agroteknologi dari :

Skema PPUPIK yang bermitra dengan UPT telah memanfaatkan lahan yang disediakan dengan berhasil menanami lahan tersebut se luas 1,1 Ha tanaman singkong yang diambil daun dan beberapa tanaman sayur lain. Vacuum sealer juga menambah peralatan di UPT untuk pemasaran daun singkong kering. 
Beberapa pelatihan sudah diberikan kepada para mahasiswa dan pengelola UPT sehingga kemampuan dalam teknik budidaya tanaman singkong semakin meningkat. Mulai dari persiapan tanam, penananam, panen. Diupayakan panen selalu dijaga kualitas dan kontinyu

Pelatihan peningkatan manajemen telah mengarahkan para pengelola dan mahasiswa untuk membuat pembukuan sederhana yang berisi tentang jadwal tanam, jadwal jaga UPT, jadwal panen, dan pembukuan keuangan UPT.

Panen yang sudah dijadwal dan daftar pelanggan akan diantar oleh para mahasiswa yang piket di bagian pemasaran.

Pelanggan rutin adalah dapur Unida Gontor dan Rumah makan Padang, dan ada juga pembeli diluar 2 pelanggan tersebut.

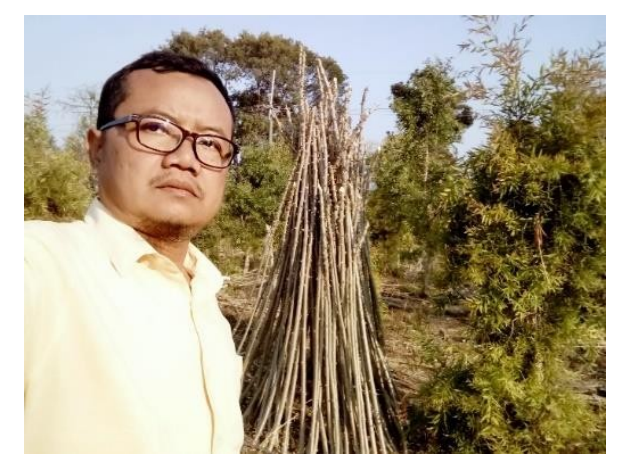

Gambar 2. Proses pembelian bibit / batang tanaman
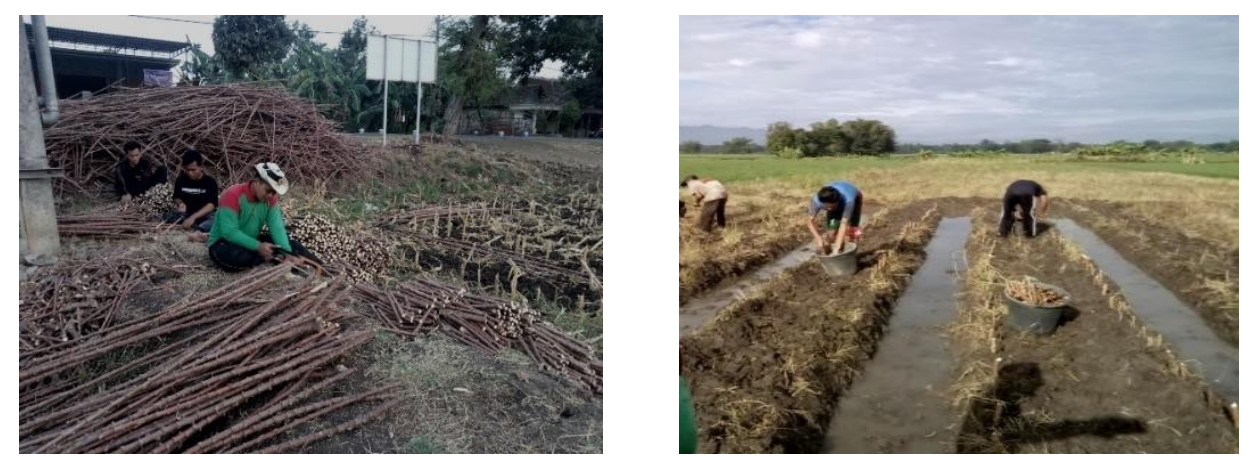

Gambar 3. Persiapan tanam

1. Menyiapkan lahan yang siap tanam

2. Menyiapkan bibit / batang tanaman singkong dengan berbagai type daun

3. Penanaman, pemeliharaan

4. Panen dan Pasca panen

Kehadiran skema PPUPIK di UPT Agroteknologi sangat bermanfaat bagi pengelola, mahasiswa dan Dosen Agroteknologi. Pelatihan yang diberikan telah meningkatkan kemampuan teknik budidaya tanaman singkong, pembuatan buku kas sederhana, jadwal piket UPT.

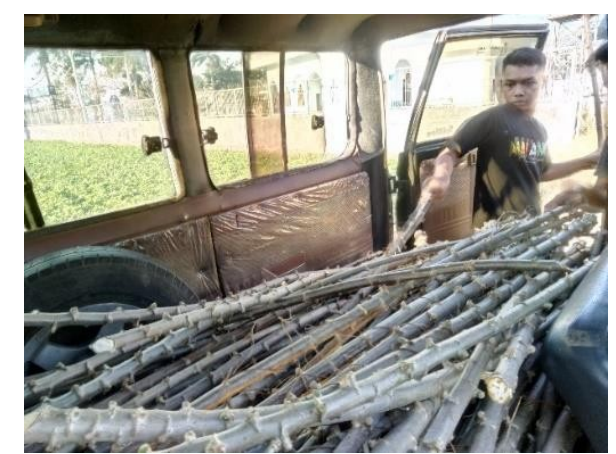
sayuran lain mempunyai potensi untuk diperluas - Langkah - langkah yang dilakukan dalam teknik budidaya tanaman singkong di lahan UPT Agroteknologi berdasar SOP (Isnatin dan Etica, 2021) menyatakan: 

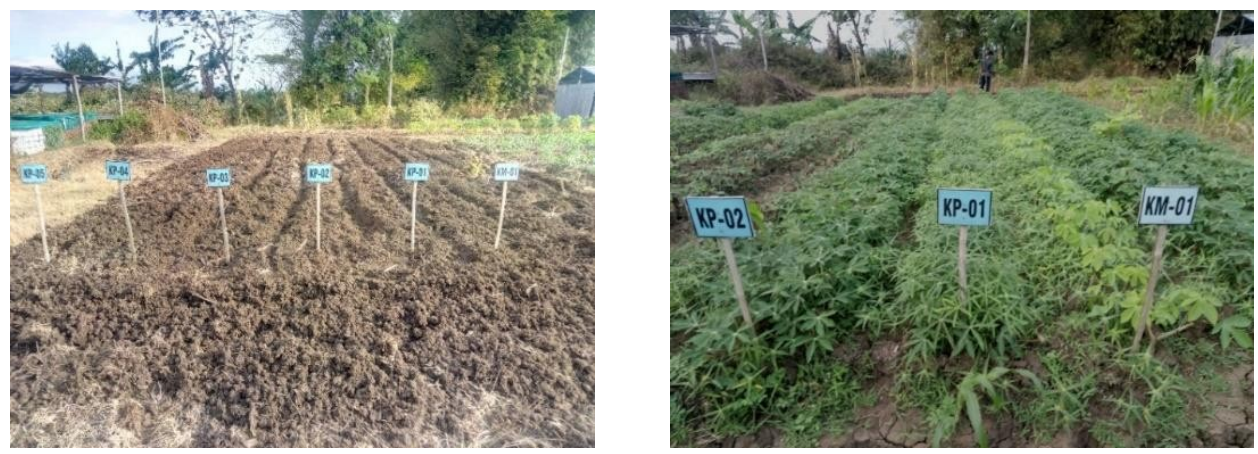

Gambar 4. Uji coba tanam dengan berbagai type daun
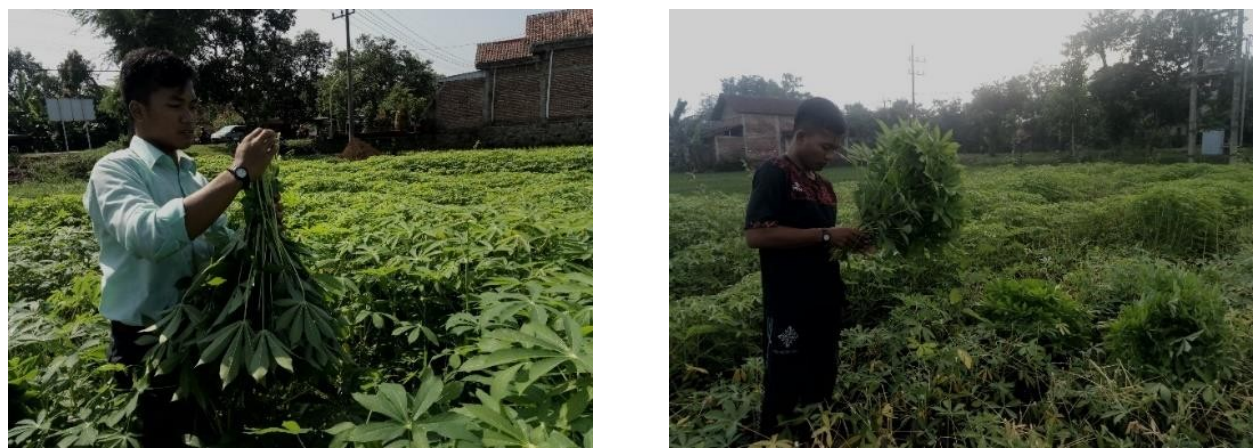

Gambar 7. Panen daun singkong
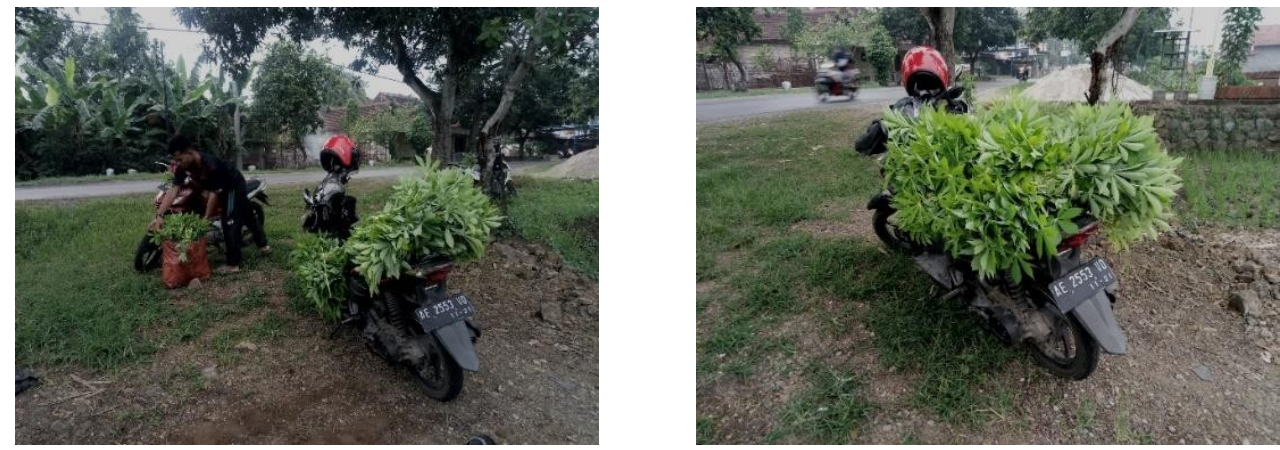

Gambar 6. Pemasaran daun singkong
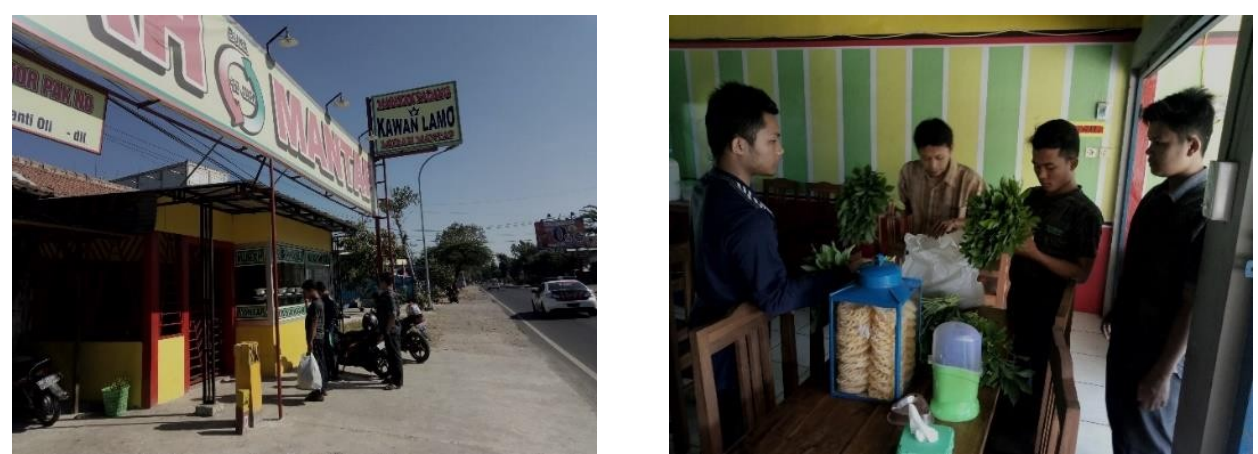

Gambar 7. Pemasaran panen daun singkong ke Rumah makan Padang 

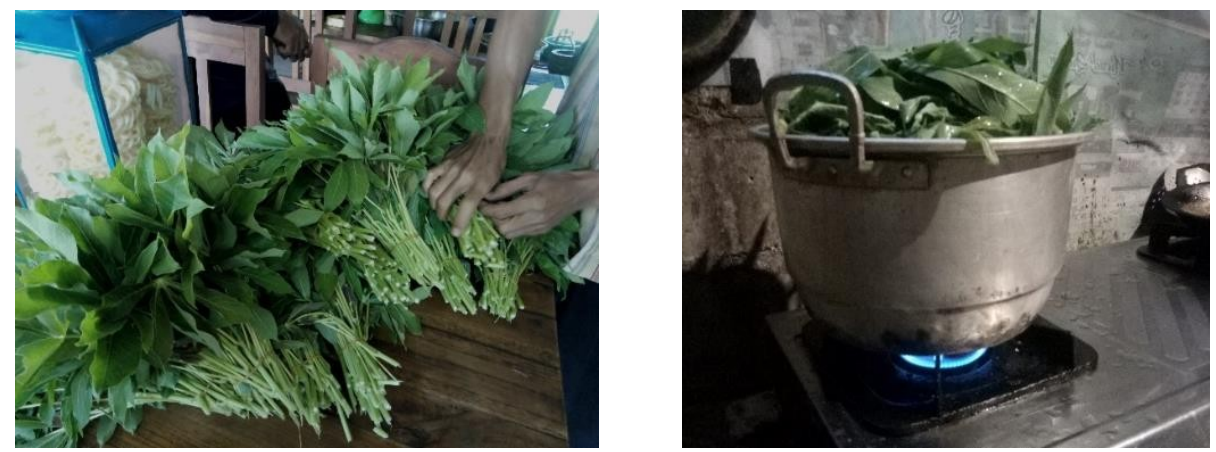

Gambar 8. Penanganan Pasca Panen
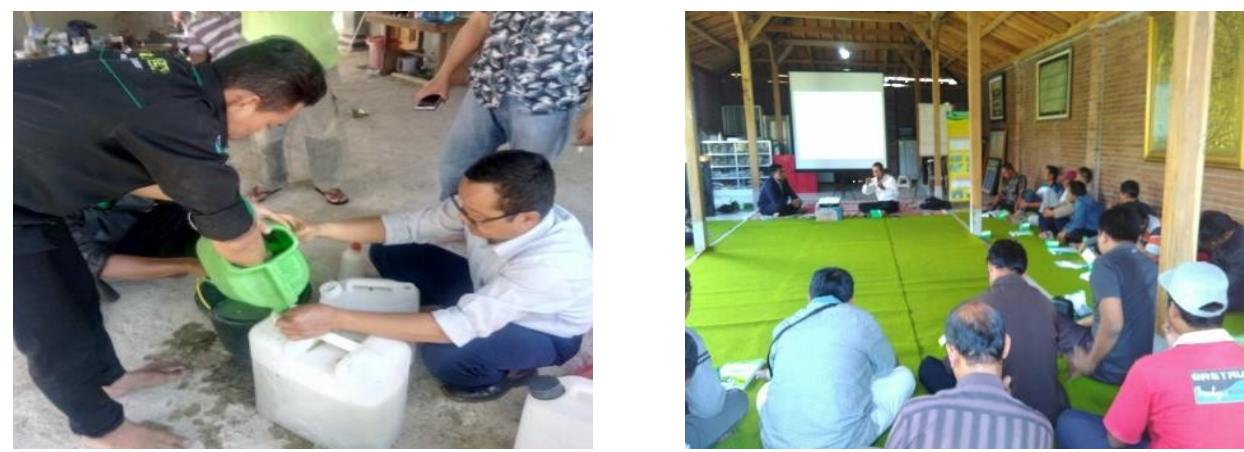

Gambar 9. Suasana pelatihan pembuatan POC dan peningkatan kemampuan managemen

Dari beberapa gambar diatas menggambarkan bahwa tahapan metode sudah dilaksanakan mulai dari praktek langsung budidaya tanaman singkong yang diambil daun, perluasan lahan, membangun jaringan pemasaran di dapur UNIDA Gontor dan Rumah Makan Padang, dan pelatihan-pelatihan kepada para mahasiswa di UPT dan petani organik di sekitar Ponorogo.

Proses budidaya tanaman singkong sudah dilaksanakan sampai panen. Inovasi pasca panen juga dilakukan supaya income UPT meningkat (Riyanto, 2008). Inovasi untuk daun singkong adalah di rebus kemudian dikeringkan dan di packing. Konsumen kemasan kering biasanya para calon jemaah Umroh atau Haji.

Pemasaran hasil panen daun singkong dilakukan oleh para mahasiswa bagian pemasaran langsung diantar ke lokasi dapur UNIDA atau Rumah Makan Padang (Tabel.2) Tujuan langsung diantar adalah untuk memperpendek rantai pemasaran sehingga pengeluaran dapat ditekan.

Tabel 2. Daftar Rumah Makan Padang di Kota Ponorogo

\begin{tabular}{lllc}
\hline No & \multicolumn{1}{c}{ Rumah Makan Padang } & \multicolumn{1}{c}{ Alamat } & $\begin{array}{c}\text { Kebutuhan daun } \\
\text { singkong (ikat) }\end{array}$ \\
\hline 1 & Lapao Padang Permato Bundo & Jl Urip Sumoharjo & 55 \\
\hline 2 & RM Ampera kapau & Jl. Urip Sumoharjo & 25 \\
\hline 3 & RM Ngebrugan & Jl. Ki Ageng Kutu & 30 \\
\hline 4 & RM Padang Jawa & Jl. Diponegoro & 23 \\
\hline 5 & RM Citra Minang & Jl. Trunojoyo 86 & 20 \\
\hline 6 & RM Citra Minang & Banyudono 255 & 30 \\
\hline 7 & RM Citra Sari & Jl. Sultan Agung & 60 \\
\hline 8 & RM Padang Solok Sakato & Jl. Gatot Subroto & 25 \\
\hline 9 & RM Singgalang & Jl. Gatot Subroto & 30 \\
\hline 10 & RM Padang suko rame & Jl. Pramuka Ronowijayan & 25 \\
\hline 11 & RM Rizky Minang & Jl. Pramuka Ronowijayan & 25
\end{tabular}




\begin{tabular}{lllc}
\hline No & \multicolumn{1}{c}{ Rumah Makan Padang } & \multicolumn{1}{c}{ Alamat } & $\begin{array}{c}\text { Kebutuhan daun } \\
\text { singkong (ikat) }\end{array}$ \\
\hline 12 & RM Kawan Lamo 1 & Slatan Pasar Pon & 30 \\
\hline 13 & RM Kawan Lamo 2 & Dengok & 10 \\
\hline 14 & RM Padang & Dengok & 12 \\
\hline 15 & RM Padang suko rame & Depan PCC & 15 \\
\hline 16 & RM Padang sukorame & Utara BRI Brahu & 20 \\
\hline 17 & RM Padang Sutan Muda & Jl Baru Suromenggolo & 12 \\
\hline 18 & RM Tuah Bundo & Jl. Basuki Rahmat & 10 \\
\hline 19 & RM Padang & Depan polsek mlarak & 25 \\
\hline 20 & RM Padang & Jl A. Yani Ponorogo & 20 \\
\hline 21 & RM Citra Sari Jabung & Jl. Raya Kutu Jabung & 25 \\
\hline 22 & RM Padang & Barat Polsek Mlarak & 25 \\
\hline 23 & RM Padang & Slatan prapatan Jabung & 25 \\
\hline
\end{tabular}

Kemampuan managemen para mahasiswa yang melakukan wirausaha di UPT juga dilatih mulai dari membuat Analisis usaha tani dari setiap usaha yang ditekuni, sehingga dapat menghitung untung rugi dan mengambil tindakan yang tepat untuk langkah berikutnya. Pembukuan tentang neraca keuangan usaha walaupun dalam skala kecil juga sudah mulai dirapikan (Tabel.3). Penghitungan analisa usaha tani sesuai dengan pemasukan dan pengeluaran selama proses budidaya (Agustina, 2011).

Asumsi kebutuhan daun singkong di

Rumah Makan Padang bila UPT

Agroteknologi dapat memenuhi : Rata - rata

25 ikat $\times 23 \mathrm{RM}=575$ ikat
@ $\operatorname{Rp} 2.000=\operatorname{Rp} 1.150 .000 /$ hari

Sebulan Rp 34.500.000,-

Secara riil masih bisa melayani 2 RM padang dengan kemampuan@30 ikat/hari dan dapur Unida hanya mampu 2 dapur dengan kemapuan@40 ikat, Sehingg pendapatan per bulan sebagai berikut:

1. Melayani 2 RM Padang X 30 ikat X Rp 2.000,- X 30 hari $=$ Rp. 3.600 .000

2. Melayani 2 Dapur Unida $X 40$ ikat/ minggu $X$ Rp 2.000,- X 4 kali $=\mathrm{Rp}$ 640.000,-

Sehingga pendapatan per bulan $(3.600 .000+$ $640.000)=$ Rp.4.240.000,-

Tabel 3. Analisa Usahatani budidaya tanaman singkong untuk sayur

\begin{tabular}{|c|c|c|c|c|c|}
\hline No & Uraian & Satuan & $\begin{array}{c}\text { Harga Satuan } \\
\text { (Rp) }\end{array}$ & Jumlah & Total (Rp) \\
\hline \multirow[t]{2}{*}{$\mathrm{I}$} & Biaya Tetap & & & & \\
\hline & $\begin{array}{l}\text { Sewa Lahan } 1.400 \mathrm{~m} 2 \text { (1 } \\
\text { kotak) selama } 6 \text { bulan }\end{array}$ & Paket & 1.750 .000 & 1 & 1.750 .000 \\
\hline II & Biaya tidak tetap & & & & \\
\hline 1. & Bibit ketela & Paket & 1.000 .000 & 1 & 1.000 .000 \\
\hline 2. & $\begin{array}{l}\text { Tenaga kerja potong bibit } \\
\text { ketela }\end{array}$ & HKP & 80.000 & 8 & $\begin{array}{l}640.00 \\
0\end{array}$ \\
\hline 3. & Persiapan lahan & HKP & 80.000 & 13 & 1.040 .000 \\
\hline 4. & Tanam & HKW & 60.000 & 8 & 480.00 \\
\hline 5. & Pengairan & Hari & 50.000 & 8 & 400.00 \\
\hline 6. & Pupuk organik cair bio urine & Liter & 100 & 2.000 & 200.00 \\
\hline 7. & Pemeliharaan & Paket/bln & 200.000 & 6 & 1.200 .000 \\
\hline 8. & Panen (mulai bln ke 2 s/d ke 6 ) & Hari (1/3 HKP) & 20.000 & 150 & 3.000 .000 \\
\hline & Total Biaya & & & & 9.710 .000 \\
\hline
\end{tabular}




\begin{tabular}{|c|c|c|c|c|c|}
\hline No & Uraian & Satuan & $\begin{array}{c}\text { Harga Satuan } \\
\text { (Rp) }\end{array}$ & Jumlah & Total (Rp) \\
\hline & Panen selama 5 bulan & Ikat & 2.000 & 10.600 & 21.200 .000 \\
\hline & panen/ bulan (mulai bulan ke 2) & Ikat & 2.000 & 2.120 & 4.240 .000 \\
\hline & Panen setiap minggu & Ikat & 2.000 & 530 & 1.060 .000 \\
\hline
\end{tabular}

$\mathrm{R} / \mathrm{C}$ ratio $=21.200 .000 / 9.710 .000=2,183$

Dengan nilai $\mathrm{R} / \mathrm{C}$ ratio $=2,183$ setiap pengeluaran biaya $\mathrm{Rp} 1.000 .000$,- akan mendapatkan Rp. 2.183.000,-. Kesimpulan hasil perhitungan analisis usaha tersebut sangat layak untuk dikembangkan.

\section{SIMPULAN DAN SARAN}

Tim PPUPIK telah berhasil menangani berbagai permasalahan mitra (UPT Agroteknologi) melalui beberapa metode yang sudah dilakukan, yaitu Analisis usahatani daun singkong dengan nilai $\mathrm{R} / \mathrm{C}$ ratio 2,183 , artinya usaha budidaya tanaman daun singkong layak untuk dikembangkan . Sehingga mahasiswa didampingi praktek teknik budidaya tanaman singkong dari persiapan lahan, tanam, pemeliharaan, panen dan pasca panen. Selain itu kemampuan manajemen di pembukuan, pemasaran juga ditingkatkan. Saran dari Tim adalah mahasiswa dan dosen yang berkecimpung di UPT agar lebih maksimal dalam menekuni usaha yang sudah dirintis, supaya tidak berhenti begitu saja dapat diteruskan ke adik kelas.

\section{UCAPAN TERIMA KASIH}

Disampaikan terimakasih kepada Yayasan Pondok Modern Gontor, Universitas Darussalam Gontor, Ketua LPPM, yang telah memberikan bantuan dana dan pendampingan dalam Hibah Internal Skema Program Pengembangan Usaha Produk Intelek Kampus (PPUPIK) bagi Unit Pelaksana Teknis (UPT) Agroteknologi Universitas Darussalam Gontor.

\section{DAFTAR PUSTAKA}

Agus, Bintoro dan Harris,N. (2006) Analisis Jaringan Pemasaran Komoditas Sayuran, Jurnal MPI Vol. 1 No. 2. September 2006,12-13

Agustina, S.(2011). Ilmu Usahatani; Universitas Brawijaya Press, Malang. 110-113

Askar, S. 1996. Daun Singkong dan Pemanfaatannya Terutama Sebagai Pakan Tambahan. Wartazoa vol 5 No 1. Balai Penelitian Ternak. Bogor. 4-5.

Isnatin U dan Etica U (2021). Standar Operasional Prosedur / SOP Budidaya Tanaman Ketela Untuk Sayuran Daun , UNIDA Press. 16-17

Lakitan,,B (1996). Fisiologi Pertumbuhan dan Perkembangan Tanaman. Raja Grafindo Persada, Jakarta, 222

Mien K. M, Slamet S, D, Apriyantono, Hermana, (1990) Komposisi Zat Gizi Pangan Indonesia. Departemen Kesehatan Republik Indonesia, Direktorat Bina Gizi Masyarakat dan Sumberdaya Keluarga,Libraries Unlimited, Fakultas Pertanian, Institut Pertanian Bogor. Bogor, 135

Riyanto,S (2018), Strategi pedagang sayur dalam menghadapi ketidak pastian pasar, Prosseding Seminar Nasional Pembangunan Pertanian III, Perhimpunan Pertanian Ekonomi Indonesia, UB. Malang, 206 